\title{
Nexus 2000 Post Conference Workshop Tour
}

Timothy Brown

On Thursday, 8 June 2000, after the Nexus 2000 paper sessions were complete, a group of 11 departed Ferrara for the post-conference workshop tour to Venice. The group, led by Prof. Tim Brown form the College of Architecture at IIT, had the pleasure of a picture perfect day in Venice with clear blue skies and warm temperatures. As usual, the arrival at the canal-side station in Venice along with the vaporetto ride along the Canale Grande to Piazza San Marco set the tone for the day's work. Participating in the workshop were Stephen Wassell, William Sapp, Paul Calter, David and Ruth Speiser, Yvonne Dold Samplonius, Albrecht Dold, Rachel Fletcher, Susan Knight and Kim Williams. The theme of this year's workshop tour dealt with works by two architects from the Veneto who bracket the idea of modernity, Andrea Palladio and Carlo Scarpa. Both of these architects have been discussed in the pages of the Nexus Network Journal (see Stephen R. Wassell, “The Mathematics of Palladio's Villas: Workshop '98, NNJ 1 (1999), pp. 121-128; Vera W. de Spinadel, “Triangulature' in Andrea Palladio", NNJ 1 (1999), pp. 117 119; Marco Frascari, "Architectural Traces of an Admirable Cipher: Eleven in the Opus of Carlo Scarpa", NNJ 1 (1999), pp. 7-22). The purpose of the workshop tour was to allow participants to experience firsthand the relationships between architecture and mathematics discussed both during the conference and in the NNJ. Palladio's vast influence abroad via the many published editions of his treatise marks an important evolution of the role of the architect in the making of buildings while Scarpa's finely-wrought work comes amidst the abandonment of close on-site involvement and collaboration with artisans during construction by the architectural profession at large. The extensive technical training that informs Palladio's treatise could be considered to find its natural conclusion in the obsessive devotion to craft that characterizes Scarpa's work.

The itinerary for the morning saw visits to Scarpa's 1958 Olivetti Showroom (currently occupied by a tenant of stunning idiocy) and his 1963 renovation of the entry level and garden at the Fondazione Querini-Stampalia. After lunch in the Campo Santa Maria Formosa, the group walked to San Francesco della Vigna to see Palladio's facade, built onto Sansovino's remarkable church, before taking the vaporetto from the Fondamenta Nuova to the island of San Giorgio Maggiore and the Giudecca. Visits to Palladio's three churches (S. Giorgio Maggiore, Le Zitelle, and Il Redentore) occupied the remainder of the afternoon. The afternoon session of the workshop was a complement to the 1998 Palladio workshop tour. The 1998 tour had concentrated only on Palladio's villas, so the afternoon session of the 2000 tour permitted the group to experience another aspect of the Vicentine architect's work.

First published in the NNJ online July 2000

\section{The reporter}

Timothy Brown is a Studio Professor and the Director of the European Study Program at the Illinois Institute of Technology College of Architecture. He is an architect and the founder and principal of Atelier FLIR, a collaborative architectural/urban design practice based in Chicago and Montepulciano, Italy. He was the coDirector (with Bob Somol) of the Joint Center for the Study of the City which produced "Spec-X", a proposal for a new master plan for Chicago.

Nexus Network Journal - Volume II, 2000 